\title{
MENDIALOGKAN RANCANGAN UNDANG-UNDANG PESANTREN DAN PENDIDIKAN KEAGAMAAN
}

\author{
Yosef Heristyo Endro Baruno ${ }^{1}$, Rinto Hasiholan Hutapea ${ }^{2}$, Yudhi Kawangung 3 \\ ${ }^{1}$ Sekolah Tinggi Teologi Magelang \\ ${ }^{2}$ Institut Agama Kristen Negeri Palangka Raya \\ ${ }^{3}$ Sekolah Tinggi Agama Kristen Teruna Bhakti Yogyakarta \\ 1Jl. Soekarno Hatta No.64-66, Kaliran, Blondo, Mungkid, Magelang, Jawa Tengah 56512 \\ 2Jl. Tampung Penyang RTA Milono Km. 6 Palangka Raya, Kalimantan Tengah, 73112 \\ ${ }^{3}$ Ds. Daratan 2, Sendang Arum, Kec. Minggir, Kab. Sleman, D.I. Yogyakarta 55562 \\ Email:dewiyosep8183@gmail.com ${ }^{1}$,rintobutapea81@gmail.com²,ykawangung06@gmail.com³
}

\begin{abstract}
ABSTRAK: Berdialog adalah sebuah upaya menyampaikan informasi dan pendapat untuk mempertimbangkan agar bisa saling memahami. Berkaitan polemik Rancangan UndangUndang Pesantren dan Pendidikan Keagamaan khususnya pasal 69 dan 70 yang telah disusun oleh DPR bersama pemerintah selaku pembuat Undang-Undang di Indonesia, telah direspons oleh masyarakat luas, terutama lembaga keagamaan Katolik dan Kristen Protestan yang sebagian besar menolak Rancangan Undang-Undang tersebut. Polemik itu berkaitan dengan niat DPR dan pemerintah yang hendak memberi payung hukum bagi penyelenggaraan kegiatan-kegiatan keagamaan yang ada di Indonesia. Penelitian ini menggunakan metode kualitatif yang menekankan analisis pada proses penyimpulan deduktif atau induktif, serta analisis terhadap dinamika hubungan fenomena yang diteliti dengan menggunakan logika ilmiah. Hasil dari penelitian ini adalah Rancangan UndangUndang tersebut mendapat tanggapan secara luas dari masyarakat dan lembaga keagamaan, khususnya pasal yang ditujukan bagi pelaksanaan kegiatan keagamaan umat Katolik dan Kristen Protestan. Polemik tersebut membuat berbagai pihak, baik pemerintah maupun lembaga keagamaan mengoreksi isi Rancangan Undang-Undang tersebut dan sementara dihentikan proses pengesahannya.
\end{abstract}

Kata Kunci : dialog; RUU pesantren; pendidikan keagamaan

\section{DIALOGUING THE LAW DRAFT OF PESANTREN AND RELIGIOUS EDUCATION}

\begin{abstract}
Dialogue is an effort to convey information and opinions to consider to understand each other. The Draft Law on Islamic Boarding Schools and Religious Education, especially articles 69 and 70, which have been drafted by the House Representative (DPR) together with the government as legislators in Indonesia, has been responded to by the wider community, predominantly Catholic and Protestant Christian religious institutions, which mostly reject the Draft Law. The polemic is related to the DPR and the government's intention to provide a legal umbrella for the implementation of religious activities in Indonesia. This study uses a qualitative method that emphasizes the analysis of the deductive or inductive inference process and analyses the dynamics of the
\end{abstract}


relationship of the phenomena using scientific logic. The result of this research is that the Draft Law has received a wide response from the public and religious institutions, especially the articles aimed at the implementation of religious activities of Catholics and Protestant Christians. The polemic caused various parties, both the government and religious institutions, to correct the Draft Law's contents and temporarily halted the process of ratifying the Draft Law into a permanent and binding Law.

Keywords: dialogue; pesantren draft law; religious education

\section{PENDAHULUAN}

Dalam rangka mengatur dan menertibkan semua kegiatan penyelenggaraan pendidikan di Indonesia, maka DPR dan pemerintah yang memiliki wewenang sesuai pasal 20 ayat 1,2 dalam UUD 1945, membuat Undang-Undang Sistem Pendidikan Nasional Indonesia (SISDIKNAS). Dalam UU SISDIKNAS No 20 tahun 2003 pada pasal 13 ayat 1 , disebutkan bahwa jalur pendidikan terdiri dari pendidikan formal, non formal dan informal. Kategori pendidikan formal adalah jalur pendidikan yang terstruktur dan berjenjang yang terdiri atas pendidikan dasar, pendidikan menengah dan pendidikan tinggi. Sedangkan pendidikan non formal adalah jalur pendidikan di luar pendidikan formal yang dapat dilaksanakan secara terstruktur dan berjenjang, dan pendidikan informal adalah jalur keluarga dan lingkungan. Dari kategori jalur pendidikan seperti disebutkan, maka dengan jelas bahwa pendidikan yang dilaksanakan oleh lembaga keagamaan merupakan kategori pendidikan non formal, seperti Sekolah Minggu dan katekisasi dalam gereja.

Seluruh jalur pendidikan yang ada di Indonesia sesungguhnya memiliki tujuan yang tercantum dalam UU SISDIKNAS nomor 20 tahun 2003 pasal 3, yaitu mengembangkan potensi peserta didik agar menjadi manusia yang beriman dan bertakwa kepada Tuhan Yang Maha Esa, berakhlak mulia, sehat, berilmu, cakap, kreatif, mandiri, dan menjadi warga negara yang demokratis serta bertanggung jawab. Berdasarkan tujuan pendidikan tersebut, maka seluruh pelaksanaan pendidikan berfungsi membentuk dan membawa peserta didik memiliki karakter yang dewasa baik secara religius maupun pengetahuanya sebagai manusia Indonesia. Hal ini karena seseorang yang memperoleh pendidikan, maka akan termotivasi untuk menjadi lebih baik dalam semua aspek kehidupan. Sehingga dengan pendidikan juga merupakan salah satu syarat untuk memajukan bangsa kita, oleh karena itu pendidikan dimulai sejak dini.

Salah satu tugas DPR dan pemerintah yaitu memperhatikan pelaksanaan pendidikan. Oleh karena itu DPR dan pemerintah belum lama ini memunculkan RUU Pesantren dan Pendidikan Keagamaan yang mengatur pendidikan jalur non formal agar pelaksanaannya yang selama ini dilakukan oleh lembaga keagamaan memiliki payung hukum, misalnya lembaga pendidikan Islam yang melakukan kegiatan pendidikan di pesantren, atau pendidikan yang dilakukan oleh lembaga keagamaan yang lainya. Pasal 69 dan 70 dari RUU tersebut mendapat tanggapan yang luas oleh masyarakat dan lembaga keagamaan Kristen Protestan dan Katolik yang menentang RUU tersebut. Penolakan seperti ini wajar terjadi pada setiap RUU sebelum disyahkan menjadi UU. Untuk kasus RUU Pesantren dan Pendidikan Keagamaan pasal 69 dan 70 ditanggapi dengan penolakan secara luas. Tentu saja ada banyak argumen untuk menolak RUU tersebut. Namun inti dari penolakan sesungguhnya bermula karena belum adanya kesepahaman antara pembuat RUU dengan pelaksananya. Menurut penulis banyak faktor yang menyertainya antara lain karena kurang sosialisasi ketika RUU itu dikonsepkan dan dimunculkan. 
RUU tersebut saat ini sedang ditunda proses untuk disahkan menjadi UU. Semoga kesempatan ini dipakai oleh DPR dan Pemerintah untuk mensosialisasikan RUU tersebut dan mendengarkan aspirasi dari pelaksana RUU tersebut, dan ini merupakan tindakan yang baik karena memberi kesempatan kepada semua pihak agar kelak setelah menjadi UU akan menjadi sesuatu yang bermanfaat dan menjawab kebutuhan bagi pembuat UU maupun pelaku UU tersebut.

Rumusan masalah dalam tulisan ini adalah bagaimana hasil dialog RUU Pesantren dan Pendidikan Keagamaan pasal 69 dan 70 yang fokusnya adalah membuat kegiatankegiatan pendidikan non formal yang diselenggarakan oleh lembaga masyarakat atau keagamaan mendapat payung hukum. Agar kegiatan-kegiatan keagamaan tersebut mendapat perlindungan hukum yang syah.

\section{METODE}

Metode penelitian pada dasarnya merupakan proses kegiatan mencari kebenaran terhadap fenomena ataupun fakta yang terjadi dengan cara yang terstruktur dan sistematis. Dalam penelitian ini penulis menggunakan metode kualitatif yang menekankan analisis pada proses penyimpulan deduktif atau induktif serta analisis terhadap dinamika hubungan fenomena yang diteliti dengan menggunakan logika ilmiah. Penulis mengumpulkan informasi yang relevan dengan topik. Informasi diperoleh dari berbagai sumber seperti buku, artikel jurnal dan sumber relevan lainnya. Informasi yang dikumpulkan tersebut akan diolah untuk mendapatkan hasil dan kesimpulan terkait rancangan undang-undang pesantren dan pendidikan keagamaan teologi.

\section{HASIL DAN PEMBAHASAN}

\section{Isi Dialog}

Dialog merupakan sebuah percakapan yang dilakukan antara dua orang atau lebih, sehingga dialog dapat diartikan sebagai komunikasi mendalam yang mempunyai tingkat serta kualitas yang tinggi yang mencakup kemampuan untuk mendengarkan serta juga saling berbagi pandangan antara satu sama lain. Dialog merupakan bentuk komunikasi interpersonal di mana dalam dialog terjadi kegiatan berbicara, bercakap, bertukar pikiran dan gagasan secara bersama, sehingga mereka saling mengerti, memahami, menerima, hidup damai, dan bekerja sama untuk mencapai tujuan atau kesejahteraan bersama. Dengan demikian dialog yang dimaksudkan di sini adalah untuk menyampaikan informasi, data, fakta, pemikiran, gagasan, dan pendapat serta berusaha mempertimbangkan agar memahami dan menerima, untuk menuju pengertian dan pemahaman yang lebih luas dan mendalam tentang hal yang menjadi bahan dialog.

Ketika seseorang mengadakan dialog harus memenuhi syarat-syarat agar: (1) Memahami dengan benar maksud, serta tujuan dari dialog atau percakapan; (2) Mempunyai pendidikan atau pengetahuan mengenai topik yang akan menjadi bahan dialog; (3) Memiliki kehendak yang baik untuk mencari kebenaran dalam dialog. Sebab itu dalam mendengarkan dialog seharusnya bersikap terbuka, tidak berprasangka buruk, dan tidak memihak atau netral; (4) Menciptakan suasana yang damai dan tenang, jauh dari emosi dan rasa paling hebat, harus menyampaikan argumen dengan baik, jelas dan mudah dipahami; (5) Dalam keseluruhan dialog harus bersikap jujur, tidak manipulatif, tulus, dan tidak mencari-cari kelemahan dan kekurangan; (6) Dialog dapat digunakan sebagai cara untuk langsung membahas suatu hal ataupun sebagai pendahuluan untuk pembahasan materi yang memang berat dan sulit.

Berdasarkan syarat dialog tersebut maka dalam penulisan di bawah ini hendak disampaikan bahan dialog atau pokok pikiran 
terkait dengan RUU Pesantren dan Pendidikan Keagamaan terutama pasal 69 dan 70. RUU tersebut dihasilkan oleh komisi VII DPR sebagai hasil dari sidang pertama di Senayan Jakarta. Mengapa hanya pasal 69 dan 70, karena pada pasal tersebut ketika RUU ini dimunculkan, mendapat tanggapan dari lembaga keagamaan maupun tokoh agama secara individu. Mereka mengkritisi dan menyampaikan pandangan-pandangannya yang sebagian besar kurang setuju dengan isi butir-butir dari pasal tersebut. Oleh karena itu maka melalui artikel ini, penulis turut menyampaikan pemikirannya dengan cara menguraikan pokok pemahaman materi dari isi pasal 69 dan 70 yang di ambil berdasarkan sumber-sumber yang dipercaya, untuk dijadikan sebagai bahan pertimbangannya. Sehingga maksud dari mendialogkan kembali dalam artikel ini adalah meninjau kembali atau mengkomunikasikan kembali tanggapan yang meluas mengenai RUU tentang Pesantren dan Pendidikan Keagamaan tersebut.

Adapun hasil akhirnya setelah mendialogkan dengan cara memaparkan teori dari sumber-sumber yang dipercaya, penulis hendak menyimpulkannya, dengan menilai secara jujur dan apa adanya. Dalam hal ini masingmasing diberi kesempatan dan kebebasan memaknai kesimpulan tersebut berdasarkan apa yang menjadi pertimbangan dan pemikiran dari masing-masing pendapat.

\section{Rancangan Undang-Undang Pesantren dan Pendidikan Keagamaan}

Karena masih sebuah rancangan maka RUU sifatnya belum menetap atau pasti, sehingga dapat diadakan perubahan dan penolakan serta pembatalan. RUU dibuat oleh Dewan Perwakilan Rakyat (DPR) sebagai lembaga yang resmi bertugas membuat Undang-undang (UU) dan dengan persetujuan bersama Presiden, demikian terdapat dalam UUD 1945 pasal 20 ayat 1, 2 .

UU diperlukan untuk landasan peme- rintah dan rakyat menjalankan kehidupannya sehari-hari, karena UU merupakan kumpulankumpulan prinsip yang mengatur kekuasaan pemerintah, hak rakyat, dan hubungan di antara keduanya. Begitu pentingnya UU sehingga pembuatan dan pengesahannya melalui berbagai proses yang panjang untuk menguji agar RUU setelah menjadi UU benar-benar tepat dan bermanfaat bagi berlangsungnya kehidupan berbangsa atau bernegara. Dalam artikel ini akan dibahas mengenai RUU yang berhubungan dengan lembaga keagamaan dalam kegiatan pendidikan. Begitu pentingnya kegiatan keagamaan dalam melaksanakan pendidikan bagi umatnya, oleh karena itu DPR bersama pemerintah bersepakat memperhatikan dan mengatur lembaga keagamaan dalam melaksanakan kegiatan pendidikan jalur non formal ini.

Pertama, Pendidikan Keagamaan. Pendidikan merupakan upaya yang dilakukan secara sadar untuk mendatangkan perubahan sikap, perilaku seseorang melalui pengajaran dan pelatihan (Penyusun, 1997a). Pendidikan berasal dari kata 'didik' dengan memberi awalan 'pe' dan akhiran 'an' yang mengandung arti perbuatan termasuk hal dan cara. Sedangkan pengertian keagamaan berasal dari kata 'agama' yaitu suatu ajaran kepercayaan kepada Tuhan. Mendapat awalan 'ke' dan akhiran 'an' yang bermakna sesuatu yang berhubungan dengan agama. Dari pengertian pendidikan dan keagamaan dapat disimpulkan sebagai upaya yang dilakukan secara sadar, sistematis untuk mengajarkan kepada peserta didik agar perubahan, sikap, dan perilakunya yang berhubungan dengan Tuhan.

Pendidikan keagamaan biasanya dikelola oleh masyarakat dan berbasis ajaran agama. Pendidikan keagamaan memiliki peran yang penting dalam sistem pendidikan nasional Indonesia. Pesantren sebagai salah satu lembaga pendidikan keagamaan, diakui sebagai lembaga pendidikan jalur non formal. Sesuai dengan PP nomor 55 tahun 2007 pasal 2 ayat 
1, 2 yang berbicara mengenai fungsi dan tujuan pendidikan agama, yaitu membentuk manusia Indonesia yang beriman dan bertakwa kepada Tuhan Yang Maha Esa serta berakhlak mulia dan mampu menjaga kedamaian dan kerukunan hubungan inter dan antar umat beragama. Sedangkan tujuannya mengembangkan kemampuan peserta didik dalam memahami menghayati dan mengamalkan nilai-nilai agama yang disesuaikan dengan penguasaan dalam ilmu pengetahuan dan teknologi dan seni. Pesantren dan lembaga pendidikan keagamaan lainya, mempunyai peran yang penting dalam mendidik anak bangsa. Karena itu pemerintah perlu untuk membuat peraturan dengan mengeluarkan RUU tentang pesantren, sehingga pesantren dapat diakui secara resmi sebagai sebuah lembaga pendidikan jalur non formal. Pemerintah juga akan memberikan hak dan perlindungan serta perhatian terhadap proses pendidikanya yang berlangsung di dalamnya.

Kedua, Pesantren. Pesantren adalah lembaga pendidikan tradisional umat Islam tempat mempelajari, memahami, mendalami, menghayati dan mengamalkan ajaran Islam dengan memberikan tekanan pada keseimbangan antara aspek ilmu dan aspek perilaku (Penyusun, 1997b). Sumber lain mengatakan bahwa pesantren adalah sebuah pendidikan tradisional yang para siswanya tinggal bersama dan belajar di bawah bimbingan guru yang lebih dikenal dengan sebutan kiai dan mempunyai asrama untuk tempat menginap santri (Syafe'i, 2017).

Penjelasan di atas, dapat dipahami bahwa pesantren termasuk sebuah lembaga pendidikan non formal yang didirikan oleh lembaga keagamaan (Islam), di mana siswanya khusus mempelajari seluk beluk Kitabnya untuk dimengerti yang kemudian menjadi pegangan dan tuntunan dalam kehidupannya. Sebagai lembaga pendidikan, maka pesantren memiliki pemimpin yang disebut dengan kiai, sebagai yang bertanggung jawab atas seluruh proses pendidikan dalam pesantren. Kiai di- bantu oleh para ustaz yang mengajar kitabkitab agama tertentu. Para murid yang belajar dalam pesantren disebut santri. Para santri yang belajar mungkin bertempat tinggal menetap di dalam pondok, sedangkan santri kalong bertempat tinggal di luar pondok. Sehingga santri kalong biasanya murid-murid yang berasal dari daerah sekitar pesantren.

Sebuah kelaziman jika dalam pesantren ada bangunan masjid untuk tempat sembahyang berjamaah dan tempat kiai memberikan pelajaran kepada para santrinya, demikian juga bangunan pondok untuk tempat tinggal para santri dan bangunan rumah untuk tempat tinggal kiai. Jika masjid sudah tidak dapat menampung lagi untuk kegiatan pendidikan dalam pesantren maka dibangun juga ruangruang untuk belajar berdasarkan pembedaan kelas.

Metode pengajaran pesantren terdiri atas sistem sorogan dan sistem bandongan yang menjadi ciri khas atau identitas sistem pendidikan pesantren. Pada sistem sorogan seorang santri secara individual belajar pada kiai, ustaz tertentu atau santri senior untuk membaca kitab agama, baik pada tahap pengenalan maupun tahap pendalaman. Dalam sistem bandongan atau disebut juga sistem weton, para santri belajar dari kiai atau seorang ustaz. Mereka berkumpul dengan cara mengelilingi kiai atau ustaz yang membaca, menerjemahkan, dan menjelaskan kitabnya. Karena pesantren menjadi sekolah madrasah atau sekolah umum, maka pesantren menggunakan sistem kelas. Oleh karena itu pesantren tidak lagi hanya mengajarkan ilmu-ilmu agama. Dalam perkembangannya pesantren ada yang mendirikan perguruan tinggi umum, oleh karena itu dalam pesantren terdapat berbagai jenis dan tingkat pendidikan, jenis pendidikan agama dan umum, serta tingkat dari taman kanak-kanak sampai perguruan tinggi. Kemajuan pesantren dapat menyesuaikan dan mengikuti perkembangan dalam masyarakat antara lain adanya pesantren yang sudah 
modern, mau bekerja sama dengan lembaga swadaya dan lembaga pengembangan masyarakat dari dalam dan luar negeri.

Ketiga, RUU Pesantren dan Pendidikan Keagamaan. Pemerintah bersama DPR tidak hanya memperhatikan lembaga pendidikan keagamaan yang dikelola masyarakat seperti pesantren yang dilaksanakan oleh lembaga keagamaan Islam, tapi juga memperhatikan lembaga pendidikan keagamaan lainya seperti agama Kristen Katolik dan Kristen Protestan. Hal ini tampak dalam RUU Pesantren dan Pendidikan Keagamaan pasal 69 dan 70.

RUU Pesantren dan Pendidikan Keagamaan pasal 69 berisi 4 ayat dan pasal 70 berisi 2 ayat. Adapun bunyi dari pasal tersebut adalah :

Pasal 69

Ayat 1: Pendidikan keagamaan Kristen jalur pendidikan nonformal sebagaimana dimaksud dalam pasal 56 diselenggarakan dalam bentuk Sekolah Minggu, Sekolah Alkitab, Remaja Gereja, Pemuda Gereja, Katekisasi, atau bentuk lain yang sejenis.

Ayat 2: Pendidikan keagamaan Kristen nonformal sebagaimana dimaksud pada ayat 1 diselenggarakan oleh gereja, organisasi kemasyarakatan Kristen dan lembaga sosial keagamaan Kristen lainya dapat berbentuk satuan pendidikan atau program.

Ayat 3: Pendidikan keagamaan Kristen nonformal sebagaimana dimaksud pada ayat 1 diselenggarakan dalam bentuk program yang memiliki peserta paling sedikit 15 orang peserta didik.

Ayat 4: Pendidikan keagamaan Kristen nonformal yang diselenggarakan dalam bentuk satuan pendidikan atau yang berkembang menjadi satuan pendidikan wajib mendapat izin dari kantor Kementerian Agama kabupaten/kota setelah memenuhi ketentuan tentang persyaratan pendirian satuan pendidikan sebagaimana dimaksud dalam pasal 19 ayat 2 .

Pasal 70

Ayat 1: Pendidikan keagamaan Kristen nonformal bertujuan untuk melengkapi Pendidikan Agama Kristen yang diperoleh di Sekolah Dasar/Sekolah Dasar Teologi Kristen, Sekolah Menengah Pertama/Sekolah Menengah Pertama Teologi Kristen, Sekolah Menengah Atas/Sekolah Menengah Teologi Kristen/Sekolah Menengah Agama Kristen atau di perguruan tinggi dalam rangka peningkatan keimanan dan ketakwaan peserta didik kepada Tuhan.

Ayat 2: Penyelenggaraan Pendidikan Keagamaan Kristen nonformal dapat dilaksanakan secara berjenjang atau tidak berjenjang.

Dari kedua pasal RUU tersebut, penulis menyimpulkan bahwa pemerintah mencantumkan kegiatan Sekolah Minggu, sekolah Alkitab, remaja gereja, pemuda gereja, katekisasi, atau bentuk lain yang sejenis sebagai bentuk kegiatan pendidikan keagamaan jalur non formal, dan dipandang sama dengan pesantren sebagai lembaga masyarakat yang melaksanakan pendidikannya pada jalur non formal, sehingga kegiatan-kegiatan tersebut hendak diberi payung hukum. Pertanyaan berkaitan dengan hal ini adalah mengapa pemerintah perlu memberi payung hukum terhadap kegiatan-kegiatan yang dilakukan oleh gereja tersebut. Penulis berasumsi positif bahwa kegiatan-kegiatan yang dilakukan oleh gereja sesungguhnya menjadi perhatian pemerintah.

Pemerintah bermaksud membantu dan melindunginya agar kegiatan-kegiatan tersebut syah dan terjamin aman oleh undang-undang. Hal ini terkait dan mengingat perkembangan situasi dan kondisi saat ini, di mana segala kegiatan keagamaan selalu diperhadapkan pada legalitas. Dengan adanya payung hukum akan dapat terhindar dari kasus-kasus yang pernah terjadi. Misalnya pendirian gereja di seluruh Indonesia, terutama di daerah di mana umat 
Kristiani adalah minoritas. Dengan adanya legalitas, maka pemerintah sekaligus memberi kesempatan kepada gereja untuk mendirikan dan mengembangkan kegiatan pendidikan keagamaannya yang selama ini dilaksanakan ke arah pendidikan jalur non formal. Oleh karenanya dalam RUU tersebut pemerintah membuat kriteria atau syarat untuk pelaksanaan pendidikan keagamaan supaya legal atau resmi dan terlindungi secara hukum, seperti yang tercantum dalam pasal 69 dan 70 .

Realitas ketika RUU dimunculkan ternyata mendapat tanggapan dari banyak pihak, baik individu seperti tokoh agama maupun lembaga gereja seperti gereja Katolik dan gereja Protestan. Tanggapan ketidaksetujuan dengan adanya RUU Pesantren dan Pendidikan Keagamaan pada pasal 69 dan 70, dengan memberikan argumennya dan menafsirkan rumusan RUU tersebut yang dianggap berlawanan dengan semangat UUD 1945, yaitu adanya pelembagaan pendidikan non formal dalam satuan pendidikan merupakan intervensi negara terhadap urusan aktivitas keagamaan, khususnya agama Kristen. Sesungguhnya kegiatan keagamaan Kristen yang tertera dalam pasal 69 ayat 1 adalah bentuk pelayanan, pewartaan dan peribadatan gereja. Sehingga ketika RUU ini disyahkan akan berpengaruh terhadap kegiatan keagamaan yang dilaksanakan tidak lagi berjalan sesuai kepercayaan yang berlaku pada masing-masing keyakinan agamanya melainkan dikondisikan dengan dipaksa berjalan menurut UU.

Rumusan tentang peserta paling sedikit 15 orang (pasal 69 ayat 3) dari pendidikan keagamaan Kristen non formal bertujuan untuk melengkapi pasal 70 ayat 1 dan menempatkan rumusan yang bercorak diskriminatif, sehingga hal ini bertentangan dengan amandemen UUD 1945 pasal 28 ayat 2 yang menyatakan: setiap orang berhak bebas dari perlakuan diskriminatif. Sesungguhnya kegiatan keagamaan tidak dapat dibatasi oleh jumlah karena justru kegiatan keagamaan Kristen memiliki sema- ngat kebersamaan dan persekutuan dengan meneladan semangat Kristus sendiri yang datang bukan hanya untuk beberapa orang tapi untuk semua orang yang beriman dan percaya kepada-Nya. Oleh karenya kegiatan keagamaan Kristen bukan sebagai kegiatan untuk melengkapi tetapi untuk memperdalam iman dan membangun persekutuan iman.

Tentang mendapat izin dari kantor Kementerian Agama kabupaten/kota dalam pasal 69 ayat 4 ditafsirkan bahwa negara mengintervensi agama yang berkaitan langsung dengan urusan iman agamanya. Pemerintah boleh mengintervensi agama bila ada tindakan kriminal yang mengatasnamakan agama atau dilakukan oleh penganut agama yang satu terhadap penganut agama yang lain dan secara nyata melanggar hukum. Pada pasal tersebut ada kerancuan karena mencampurkan urusan agama dan negara. Agama berurusan dengan iman dan berurusan dengan Yang Illahi, sehingga sumber iman dan tujuan iman bukanlah negara tetapi Allah. Justru negara yang diwakili oleh kementerian agama melalui bimbingan masyarakat merupakan media untuk menjembatani urusan administratif, urusan pendidikan formal dan urusan pemerintah bukan urusan iman.

Untuk mengetahui sesungguhnya apa itu kegiatan gereja yang sedang menjadi perbincangan, maka penulis menguraikan apa sesungguhnya kebaktian anak atau Sekolah Minggu sebagai cara mendialogkan RUU Pesantren dan Pendidikan Keagamaan pasal 69 dan 70 dengan pendapat yang menolak RUU tersebut. Agar dapat dipahami dan dimengerti serta menjadi kesimpulan dari masing-masing pembaca.

Menurut sejarahnya Sekolah Minggu muncul pada abad pertengahan 18, di Inggris pada masa revolusi Industri. Sekolah Minggu didirikan oleh Robert Rikes seorang wartawan yang mempunyai percetakan. Dalam keprihatinannya, ia melihat anak-anak buruh industri yang pada hari libur berkeliaran dan 
kadang melakukan tindakan-tindakan kriminal. Oleh Rikes anak-anak ini dihimpun dan dididik pada hari Minggu untuk belajar membaca, menulis, dan diajarkan disiplin dan ketertiban. Setelah pertemuan belajar tersebut, anak-anak masuk ke gereja untuk beribadah. Perjuangan Rikes yang menolong anak-anak untuk pandai membaca sesungguhnya menjadikan mereka terampil membaca Alkitab, dan akhlak anak-anak akan menjadi lebih baik dan tidak mengganggu masyarakat yang lain. Sehingga Sekolah Minggu pada awalnya didirikan untuk menolong angkatan muda agar hidup lebih tenang dalam masyarakat industri yang sedang dibangun di Inggris pada pertengahan abad ke-18.

Dalam perkembangannya usaha Rikes mendirikan Sekolah Minggu, mendapat tanggapan yang meluas dari pimpinan gereja dan masyarakat yang menyokongnya. Setelah Robert Rikes meninggal maka Sekolah Minggu disambut baik oleh gereja dan warga Kristen. Gereja mendirikan sekolahminggu sebagai sarana untuk menyelamatkan anak dari kekuatan Iblis. Sekolah Minggu akhirnya semakin berkembang luas hingga keluar wilayah Inggris, dan tersebar ke seluruh dunia, termasuk Indonesia. Oleh karena itu Sekolah Minggu menjadi bagian dari kegiatan gereja dalam rangka memperhatikan pertumbuhan dan perkembangan iman anak-anak. Perhatian gereja terhadap anak-anak, sama seperti gereja memperhatikan perkembangan dan pertumbuhan iman kaum remaja, pemuda, dewasa serta lansia.

Pendidikan Kristen dapat berlangsung dalam konteks informal, seperti keluarga dan gereja (Sidjabat, 2019). Sekolah Minggu merupakan salah satu pendidikan dalam konteks informal. Sekolah Minggu sering disebut juga sebagai kebaktian anak. Alasannya bahwa kegiatan ini sama seperti kebaktian umum yang diadakan setiap hari Minggu, karena pesertanya anak-anak, maka disebut sebagai kebaktian anak. Di dalamnya anak beribadah, berbakti kepada Tuhan, ada unsur-unsur liturgi yang dipakai, seperti nyanyian, doa, pemberitaan Firman dan persembahan syukur. Sebagai sebuah kebaktian anak, di dalamnya ada unsur guru yang mengajarkan pengetahuan iman, kurikulum sebagai bahan untuk pengajaran dan siswa atau anak sebagai peserta didik. Dalam pendidikan Kristen harus disesuaikan dengan tujuan pokok pendidikan Kristen, termasuk didalamnya pendidikan anak yaitu adalah memperlengkapi warga jemaat agar mewujudkan tanda-tanda Kerajaan Allah dalam Yesus Kristus, sambil menantikan penggenapan-Nya .

Tujuan pokok pendidikan Kristen ini sejalan dengan tujuan utama dari proses perencanaan dan pelaksanaan kurikulum Pendidikan Agama Kristen yaitu untuk menjadikan semua orang murid Kristus, membentuk manusia Indonesia secara utuh, membina pengajar, umat, dan peserta didik memperoleh perubahan hidup (Tubulau, 2020). Terkait tujuan kurikulum ini, gereja-gereja sudah melaksanakan pengembangan kurikulum Sekolah Minggu sebagai tanggapan terhadap perubahan yang hebat di bidang politik, ekonomi, dan teologi (Kawangung, 2020). Termasuk dalam menanggapi RUU Pendidikan Keagamaan di atas. Oleh sebab itu, pendidikan untuk anak harus dijabarkan dalam konteks masa kini yang kongkret agar Kerajaan Allah tidak sekadar sebagai slogan melainkan hidup secara nyata dan jelas terutama dalam konteks Indonesia yang diimplementasikan dalam kurikulum pengajaran dalam kebaktian sekolah anak.

Berdasarkan pembahasan tentang kegiatan Sekolah Minggu di atas, maka penulis dapat menarik kesimpulan bahwa Sekolah Minggu yang dimaksudkan adalah sebagai kegiatan ibadah anak yang memiliki unsur seperti dalam pendidikan jalur non formal keagamaan. Namun tentu saja masih ada beberapa syarat tambahan lain guna memenuhi kategori sebagai pendidikan jalur non formal 
seperti yang ada dalam RUU Pesantren dan Pendidikan Keagamaan pasal 69 dan 70. Selanjutnya, ada beberapa hal yang harus dipenuhi dan dipersiapkan untuk memenuhi persyaratan seperti dalam RUU di atas apabila gereja secara individu maupun kelembagaan bersepakat bahwa kegiatan-kegiatan gereja tersebut meminta perlindungan secara hukum, walaupun sesungguhnya dalam mendirikan gedung gereja juga sudah memiliki undangundangnya.

Kemudian aspek yang tidak kalah penting untuk diperhatikan terkait RUU tersebut adalah semua pihak diharapkan dapat membangun dialog dan menghindari adanya faktor egosentris keagamaan. Egosentris keagamaan dapat menyebabkan terjadinya konflik keagamaan dan rusaknya kerukunan antar umat beragama (Hutapea \& Iswanto, 2020). Oleh sebab itu, RUU yang diwacanakan pemerintah hendaknya disikapi dengan baik antar umat beragama, khususnya lembaga gereja Katolik maupun Kristen.

Aspek penting berikutnya dalam menyikapi RUU Pesantren dan Pendidikan Keagamaan di atas ialah perlu adanya gerakan yang menampilkan agama dan pendidikan Kristen dalam bingkai gerakan transnasional Kristen. Artinya, ada upaya menebarkan agama dan pendidikan Kristen di Indonesia yang dilakukan dengan kerja sama antara institusi keagamaan baik dalam bentuk badan misi atau tokoh gereja lintas Negara (Tambunan, 2019). Gerakan ini perlu untuk dipertimbangkan dalam mendialogkan pendidikan keagamaan di lembaga gereja, sehingga terjadi keharmonisan sebagai warga negara dan antar umat beragama di Indonesia.

\section{KESIMPULAN}

RUU Pesantren dan Pendidikan Keagamaan pasal 69 dan 70 mendapat tanggapan secara luas dari masyarakat dan lembaga keagamaan. Hal ini karena RUU tersebut khusus ditujukan bagi pelaksanaan kegiatankegiatan keagamaan yang selama ini dijalankan sebagai kegiatan ibadah dan pendalaman pengetahuan iman umat terutama bagi kegiatan keagamaan Kristen Katolik dan Kristen Protestan. Polemik tersebut membuat berbagai pihak baik pemerintah maupun lembaga keagamaan mengoreksi isi RUU tersebut, sehingga untuk sementara dihentikan proses pengesahannya menjadi UU.

Menurut penulis ada dua hal penting yang perlu diperhatikan. Pertama, DPR beserta pemerintah selaku pembuat RUU hendaknya mendialogkan kembali atau mengkomunikasikan dengan mengundang pihak-pihak yang terkait atau pelaksana/pelaku RUU tersebut yaitu lembaga gereja di Indonesia. Dengan demikian maka pemerintah dan lembaga gereja dapat memiliki kesepahaman akan maksud dari RUU tersebut.

Kedua, tujuan pemerintah untuk melindungi secara hukum pelaksanaan kegiatan pendidikan keagamaan non formal kiranya benar-benar membawa manfaat untuk membangun sarana dan prasarana pendidikan tersebut. Juga RUU tersebut menjaga secara hukum kegiatan pendidikan tersebut dari berbagai gangguan. Dalam hal ini pemerintah murni membantu keberlangsungan pelaksanaan pendidikanya, dan yang berhak menentukan kurikulum pengajaranya adalah lembaga agama tersebut, yang mengetahui kebutuhan peserta didiknya. Untuk itu perlu disepakati dalam RUU tersebut pasal yang berisi batasan wewenang pemerintah, sehingga kelak pemerintah tidak mengintervensi ajaranajaran bagi kegiatan pendidikan keagamaan itu. 


\section{DAFTAR RUJUKAN}

Boehlke, R. R. Sejarah Perkembangan Pikiran dan Praktek Pendidikan Agama Kristen. BPK Gunung Mulia.

Christiani, T. K. (2009). Ajarlah Mereka Melakukan. PT BPK Gunung Mulia.

Daryanto, S. (1997). Kamus Bahasa Indonesia Lengkap. Apollo.

Groome, T. H. (2018). Christian Religious Education- PAK. PT BPK Gunung Mulia.

Hutapea, R. H., \& Iswanto. (2020). Potret Pluralisme Agama dalam Masyarakat di Kota Kupang. Jurnal Dialog, 43(76), 99108. https://jurnaldialog.kemenag.go.id/ index.php/dialog/article/view/363

Kawangung, Y., R. H. Hutapea \& Y. Y. Dwianto. (2020). Pemetaan Kurikulum dan Strategi Pembelajaran Sekolah Minggu. Sabda: Jurnal Teologi Kristen, 1, 7184. http://jurnalsttn.ac.id/index.php/ $\mathrm{SJT} /$ article/view/4

Penyusun, T. (1997a). Ensiklopedi Nasinal Indonesia Buku 12. Delta Pamungkas.
Penyusun, T. (1997b). Ensiklopedi Nasinal Indonesia Buku 13. Delta Pamungkas.

Sidjabat, B. S. (2019). Meretas Polarisasi Pendidikan Kristiani: Sebuah Pengantar tentang Arah Pendidikan Kristiani di Gereja, Akademia, dan Ruang Publik. Journal of Chemical Information and Modeling, 7(1), 7-27.

Syafe'i, I. (2017). Pondok Pesantren: Lembaga Pendidikan Pembentukan Karakter. AlTadzkiyyah: Jurnal Pendidikan Islam, 8(I), 6182.

Tambunan, E. (2019). Gerakan Transnasional Kristen: Wajah Ekonomi-Politik Agama dan Pendidikan di Indonesia. Jurnal Ilmiah Religiosity Entity Humanity (JIREH), 1(1), 117. https://ojs-jireh.org/index.php/jireh/ article/view/4/10

Tubulau, I. (2020). Kajian Teoritis Tentang Konsep Ruang Lingkup Kurikulum Pendidikan Agama Kristen. Jurnal Ilmiah Religiosity Entity Humanity (IIREH), 2(1), 27-38. https://doi.org/10.37364/ jireh.v2i1.29 